\title{
POTENSI PROBIOTIK INDIGENUS Lactobacillus plantarum Dad 13 PADA YOGURT DENGAN SUPLEMENTASI EKSTRAK UBI JALAR UNGU UNTUK PENURUN DIARE DAN RADIKAL BEBAS
}

\author{
Potential Probiotic Lactobacillus plantarum Indigenous Dad 13 on Yoghurt with Purple Sweet Potato Extract \\ Supplementation to Reducing Diarrhea and Free Radicals \\ Agustina Intan Niken Tari, Catur Budi Handayani, Sudarmi \\ Program Studi Teknologi Hasil Pertanian, Universitas Veteran Bangun Nusantara, \\ J1. Letjen S. Humardani No 1 Jombor Sukoharjo 57521 \\ Email : intanniken@gmail.com
}

\begin{abstract}
ABSTRAK
Penelitian bertujuan mempelajari efektivitas strain probiotik indigenus terpilih (Lactobacillus plantarum Dad 13) pada yogurt dengan suplementasi ekstrak ubi jalar ungu sebagai penurun diare dan radikal bebas pada tikus putih albino Norway rats (Rattus novergicus) galur Sprague dawley. Penelitian dirancang menggunakan rancangan acak lengkap faktorial, dengan perlakuan yogurt ekstrak ubi jalar ungu tanpa probiotik (P0), yogurt ekstrak ubi jalar ungu dengan probiotik (P1) terhadap 2 kelompok tikus Sprague dawley jantan yang diberi perlakuan tanpa enteropathogenik Escherichia coli (EPEC) ATCC 35218 (E0) maupun dengan enteropathogenik Escherichia coli (EPEC) ATCC 35218 (E1). Pemberian probiotik dilakukan dengan metode sonde pada hari ke-1 sampai 21 dengan dosis $1 \mathrm{ml} / 120 \mathrm{~g}$ BB tikus percobaan atau rata-rata $10^{\circ} \mathrm{CFU} / \mathrm{ml}$. Sedangkan perlakuan EPEC ATCC 35218 dilakukan dengan metode sonde sebanyak $10^{6} \mathrm{CFU} / \mathrm{ml}$ pada hari ke 7 sampai ke 14. Parameter yang diamati meliputi kadar air feses, kadar air sekum, kadar malonaldehide (MDA) darah dan hati. Hasil penelitian menunjukkan bahwa (1). Terdapat interaksi perlakuan antara pemberian EPEC ATCC 35218 dan probiotik indigenous pada yogurt ekstrak ubi jalar ungu terhadap kadar air feses, kadar air sekum, kadar MDA darah dan kadar MDA hati tikus uji. (2). Kultur Lactobacillus plantarum Dad 13 yang ditambahkan pada yogurt ekstrak ubi jalar ungu mampu memberi efek kesehatan sebagai penurun diare dan radikal bebas.
\end{abstract}

Kata kunci: Pencegah diare, penurun radiakal bebas, yogurt ekstrak ubi jalar ungu, bakteri probiotik

\begin{abstract}
The purpose of this study was studying the effectiveness of selected indigenous probiotic strains (Lactobacillus plantarum Dad 13) in yoghurt with purple sweet potato extract suplementation as reducing diarrhea and free radicals on white rats albino Norway rats (Rattus novergicus) Sprague dawley strain. The study was designed using factorial completely randomized design, with treatment of purple sweet potato extract yogurt without probiotics ( $\mathrm{P} 0)$, purple sweet potato extract yogurt with probiotic (P1) to 2 groups of male Sprague dawley rats were treated without Enteropathogenik Escherichia coli (EPEC) ATCC 35218 (E0) and with Enteropathogenik Escherichia coli (EPEC) ATCC 35218 (E1). Probiotic treatment was conducted using the sonde at day $1^{\text {st }}$ to $21^{\text {st }}$ at a dose of $1 \mathrm{ml} / 120 \mathrm{~g}$ weight or average $10^{9} \mathrm{CFU} /$ $\mathrm{ml}$. While the treatment of EPEC ATCC 35218 was conducted using the sonde at dose of $10^{6} \mathrm{CFU} / \mathrm{ml}$ on day $7^{\text {th }}$ to $14^{\text {th }}$. The observed parameters include fecal water content, water content of cecum, malonaldehide levels (MDA) blood and liver. The results showed that (1) There was interaction between the treatment of indigenous probiotic yogurt purple sweet potato extract and EPEC ATCC 35218 on water content of faecal, water content of cecum, MDA levels blood and liver (2).Culture of Lactobacillus plantarum Dad 13 was able to provide health effects as reducing of diarrhea and free radicals.
\end{abstract}

Keywords: Reducing of diarrhea, free radicals, purple sweet potato extract yogurt, probiotic bacteria 


\section{PENDAHULUAN}

Probiotik adalah mikroorganisme hidup yang saat dikonsumsi dengan jumlah yang cukup tetap hidup sampai saluran pencernaan serta memberikan manfaat kesehatan bagi tubuh melalui keseimbangan mikrobiota (FAO, 2002). Menurut Parvez dkk. (2006), bakteri probiotik bermanfaat meningkatkan sistem kekebalan tubuh dan mempunyai efek kesehatan, seperti mengurangi kejadian lactose intolerance, mencegah hipertensi, dan sebagai pencegah dan mempunyai efek terapeutik melawan diare. Probiotik juga dilaporkan mampu mengatasi diare yang disebabkan oleh E.coli, baik enterotoksigenik E.coli (ETEC) (Oetayo, 2004), maupun enterohemorargi E. coli (EHEC) (Medellin- Pena dan Griffiths, 2009). Efek tersebut muncul jika jumlah bakteri hidup sampai di saluran pencernaan lebih dari $10^{6} \mathrm{CFU} / \mathrm{g}$ atau $10^{6} \mathrm{CFU} /$ $\mathrm{ml}$ (Oyetayo, 2004). Penelitian terdahulu membuktikan bahwa secara in vitro bakteri galur Lactobacillus dan Bifidobacteria dapat menghambat penempelan dan invasi bakteri enteropathogen penyebab diare (Bourlioux dkk., 2003). Persyaratan jumlah sel hidup probiotik dalam susu fermentasi minimal $10^{7} \mathrm{CFU} / \mathrm{g}$ (Codex, 2003), yang diharapkan dapat mengantisipasi penurunan jumlah sel selama melewati lingkungan ekstrem di pencernaan (Shah dkk., 2000). Beberapa peneliti juga melaporkan bahwa mengkonsumsi bakteri asam laktat (BAL) golongan Lactobacillus mampu meningkatkan sistem imun seluler dan humoral (Gackowska dkk., 2006).

Beberapa isolat lokal bakteri asam laktat yang telah berhasil diisolasi dan mempunyai sifat probiotik antara lain: Lactobacillus plantarum Mut 7 yang diisolasi dari makanan fermentasi ketela (gatot) (Rahayu, dkk., 1996), Lactobacillus plantarum Dad 13 yang diisolasi dari susu fermentasi kerbau (dadih) (Ngatirah dkk., 2000) serta Lactobacillus acidophilus SNP-2 yang disolasi dari feses bayi yang mengkonsumsi air susu ibu (ASI) (Purwandani, dan Rahayu, 2003). Untuk mempertahankan homeostatis koloni mikroflora saluran pencernaan, diperlukan adanya nutrien yang masuk ke dalam usus. Kolonisasi oleh probiotik untuk membentuk mikroekosistem yang normal dapat dimanipulasi melalui pengaturan diet yang mengandung prebiotik, probiotik atau kombinasi keduanya yang disebut sinbiotik (Rastall dan Gibson, 2004).

Para ahli saat ini sedang gencar melancarkan konsep “food as medicine." Konsep tersebut merupakan sebuah cara untuk mengoptimalkan pangan fungsional untuk membantu mengatasi penyakit. Salah satu bahan pangan fungsional berbahan lokal adalah ubi jalar ungu. Ubi jalar ungu mengandung antioksidan seperti asam phenolat, antosianin, dan 3 tokoferol yang dapat mencegah timbulnya beberapa penyakit (Woolfe, 1993). Hasil penelitian Retnati (2009) menunjukkan bahwa proses fermentasi pada pembuatan yoghurt dapat meningkatkan aktivitas antioksidan sehingga berpotensi mengurangi kadar lipid dalam darah.

Peningkatan khasiat ubi sehingga dapat dimanfaatkan secara maksimal sebagai diet alternatif perlu dilakukan, karena masyarakat masih memandang ubi jalar sebagai makanan kelas bawah. Salah satu bentuk inovasi pengolahan makanan alternatif dari ubi jalar ungu adalah yogurt.

Tari dkk. (2013) melaporkan bahwa yogurt dengan penambahan ekstrak ubi jalar ungu menggunakan kultur komersial dan probiotik indigenus, yaitu Streptococcus thermophillus FNCC 0040, Lactobacillus bulgaricus FNCC0041 dan Lactobacillus plantarum Dad 13 dengan perbandingan 1:1:0,5 merupakan yogurt terbaik diantara perlakuan-perlakuan penggunaan kultur komersial dan probiotik indigenus lainnya (kultur Streptococcus thermophillus FNCC 0040, Lactobacillus bulgaricus FNCC0041 dan probiotik Lactobacillus plantarum Mut 7 dengan perbandingan 1:1:0,5 dan kultur Streptococcus thermophillus FNCC 0040, Lactobacillus bulgaricus FNCC0041 dan probiotik Lactobacillus acidophilus SNP2 dengan perbandingan 1:1:0,5). Yogurt tersebut memiliki sifat fisik ( $\mathrm{pH}=3,78$, viskositas $=5,1987 \mathrm{cP}$, warna kromatik $=18,559$ ), sifat kimia (kadar asam tertitrasi 1,2733\%, kadar air 85, $2664 \%$, kadar abu 0,8041\%, kadar gula reduksi $3,3278 \%$, kadar protein terlarut $1,4782 \%$, kadar lemak $0,08 \%$ dan kadar antosianin 8,5315\%), sifat organoleptik dengan skor (kenampakan 2,80, rasa 4,05 dan aroma 3,35 dari skala maksimal 5). Viabilitas BAL selama dua minggu penyimpanan $10^{9} \mathrm{CFU} / \mathrm{ml}$ pada suhu $4^{\circ} \mathrm{C}$ dan aktivitas pencegah diare dengan kemampuan menurunkan enteropatogenic E.coli ATCC 35218 sampai 4 log cycle selama dua minggu penyimpanan pada suhu $4^{\circ} \mathrm{C}$ secara in vitro.

Kemampuan kultur komersial dan probiotik indigenus, yaitu Streptococcus thermophillus FNCC 0040, Lactobacillus bulgaricus FNCC0041 dan Lactobacillus plantarum Dad 13 dengan perbandingan 1:1:0,5 pada yogurt dengan penambahan ekstrak ubi jalar ungu sebagai penurun diare dan radikal bebas belum diketahui. Untuk itu maka pada penelitian ini dilakukan secara in vivo menggunakan tikus percobaan. Hipotesis dari penelitian ini adalah bahwa BAL Lactobacillus plantarum Dad 13 yang disuplementasikan pada yogurt dengan penambahan ekstrak ubi jalar ungu dapat menurunkan diare yang disebabkan oleh Enteropathogenic Escheirchia coli (EPEC) ATCC 35218 dan radikal bebas yang diindikasikan dengan menurunnya kadar malonaldehida (MDA) pada darah dan hati tikus coba (secara in vivo).

Adapun tujuan penelitian ini adalah: mempelajari efektivitas strain probiotik indigenus terpilih (Lactobacillus plantarum Dad 13) pada yogurt dengan suplementasi ekstrak ubi jalar ungu sebagai penurun diare dan radikal bebas pada 
tikus putih albino Norway rats (Rattus novergicus) galur Sprague dawley.

\section{METODE PENELITIAN}

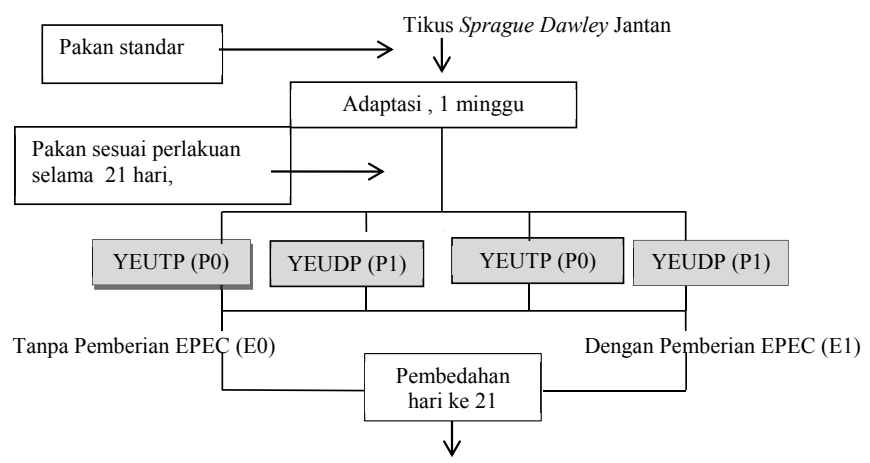

Analisis kadar air feses dan sekum

Analisis kadar MDA dalam darah dan hati

Gambar 1. Uji in vivo bakteri probiotik pada yogurt ekstrak ubi jalar ungu dan efektivitasnya sebagai pencegah diare dan penurun radikal bebas

Keterangan:

YEUTP (P0) : Yogurt dengan ekstrak ubi jalar ungu tanpa pemberian tambahan probiotik (kontrol)

YEUDP (P1): Yogurt dengan ekstrak ubi jalar ungu dan pemberian tambahan probiotik

E0 : Tanpa perlakuan enteropathogenic Escherichia coli (EPEC) ATCC 35218

E1 : Dengan perlakuan enteropathogenic Escherichia coli (EPEC) ATCC 35218

\section{Pembuatan Ekstrak Ubi Jalar Ungu}

Pembuatan sari ubi jalar ungu mengacu pada Tari (2011) yaitu ubi jalar dipotong kecil (ukuran $5 \times 5 \mathrm{~cm}$ ), kemudian dimasukkan ke dalam juicer. Produk didiamkan 30 menit sampai 24 jam pada suhu $4^{\circ} \mathrm{C}$ untuk mengendapkan patinya, kemudian diambil filtratnya. Filtrat ini merupakan ekstrak ubi jalar ungu yang siap digunakan untuk membuat yogurt.

\section{Pembuatan Starter}

Pembuatan starter dilakukan dengan menyiapkan 5 $\mathrm{ml}$ medium MRS broth steril sebanyak 3 tabung, kemudian masing-masing tabung diinokulasi dengan biakan tegak Lactobacillus bulgaricus FNCC 0041. Streptococcus thermophilus FNCC 0040, Lactobacillus plantarum Dad 13. Kesemua isolat diinkubasi pada suhu $36^{\circ} \mathrm{C}$ selama 24 jam. Pembuatan kultur starter dilakukan dengan cara memipet masing-masing $0.1 \mathrm{ml}$ biakan tersebut, kemudian menginokulasikan ke dalam $5 \mathrm{ml}$ susu skim steril, dan menginkubasinya pada suhu $43^{\circ} \mathrm{C}$ selama $7-8$ jam atau pada suhu $36^{\circ} \mathrm{C}$ selama $24 \mathrm{jam}$.

\section{Pembuatan Yogurt dengan Suplementasi Ekstrak Ubi Jalar Ungu}

Susu segar $200 \mathrm{ml}$, susu skim $(5 \% \mathrm{~b} / \mathrm{v})$ dan ekstrak ubi jalar ungu $(10 \% \mathrm{v} / \mathrm{v})$ dipasteurisasi pada suhu $72^{\circ} \mathrm{C}$ selama 15 menit, kemudian didinginkan sampai suhu 40$45^{\circ} \mathrm{C}$. Selanjutnya, diinokulasi menggunakan Streptococcus thermophillus dan Lactobacillus bulgaricus serta bakteri probiotik indigenus Lactobacillus plantarum Dad 13 dengan perbandingan $1: 1: 0,5$ yang dilakukan secara aseptis pada suhu $43-45^{\circ} \mathrm{C}$, sebanyak $5 \%(\mathrm{v} / \mathrm{v})$, kemudian dikocok hingga homogen. Susu dan ekstrak ubi jalar ungu yang telah diinokulasi dengan starter dimasukkan ke dalam botol-botol steril dan diinkubasi pada suhu $40^{\circ} \mathrm{C}$ selama $17 \mathrm{jam}$, hingga dihasilkan yogurt ekstrak ubi jalar ungu.

\section{Pengelolaan Hewan Coba}

Penelitian ini dilakukan dengan rancangan acak kelompok lengkap pola Faktorial, menggunakan hewan coba berupa tikus jantan Sprague Dawley dengan umur 2 bulan hasil pengembangbiakan dari BPOM RI, dengan bobot badan 120-130 g. Kandang yang digunakan adalah kandang individu yang berukuran $17,5 \times 23,5 \times 17,5$. Suhu ruangan diatur pada $23-24^{\circ} \mathrm{C}$ (Muchtadi, 1993). Ransum diberikan sebanyak $20 \mathrm{~g}$ per ekor per hari setiap pukul 06.00-07.00 WIB. Air minum diberikan secara ad libitum. Setiap 3 hari dilakukan penimbangan bobot badan dan pencucian kandang.

Komposisi ransum basal disusun berdasarkan standart AIN 93 (American Institute of Nutrition) 93, yang terdiri dari tepung jagung $62,069 \%$, kasein $14,0 \%$, sukrosa $10,0 \%$,minyak kedelai $4,0 \%$, selulose $5,0 \%$, mineral $3,5 \%$, vitamin $1,0 \%$, L-sistin 0,2\%, kolin-bitartrat $0,3 \%$ dan TBHQ (Tertbutylhydroquinon) $0,0008 \%$.

\section{Perlakuan terhadap Hewan Percobaan dan Pengambilan Sampel}

Tikus dibagi dalam 4 kelompok perlakuan. Selama penelitian semua tikus diberi ransum standar. Pada minggu pertama penelitian semua tikus percobaan diberi pakan standart sebagai adaptasi. Pemberian yogurt ekstrak ubi jalar ungu dengan probioik maupun tanpa probiotik dilakukan selama 3 minggu penuh,yaitu pada hari ke 1 sampai hari ke21 setelah masa adaptasi secara oral menggunakan sonde, dan dibarengi pemberian pakan standart. Populasi BAL pada yogurt ekstrak ubi jalar ungu yang diberikan adalah $10^{9} \mathrm{CFU} /$ ml setiap ekor tikus. Infeksi EPEC ATCC 35218 dilakukan dengan populasi $10^{6} \mathrm{CFU} / \mathrm{ml}$ sebanyak $1 \mathrm{ml} / 150 \mathrm{~g}$ BB tikus per hari selama 7 hari (hari ke 8 sampai ke 14), secara oral menggunakan sonde. Pembedahan tikus untuk mengetahui kadar air sekum, kadar MDA (Malonaldehehide) darah dan hati tikus dilakukan pada hari ke-21. 


\section{Pengamatan terhadap Terjadinya Diare pada Tikus Terinfeksi Enteropathogenic Escherichia Coli (EPEC) ATCC 35218}

Kejadian diare tikus percobaan diamati dengan cara mengukur kadar air feses yang dikoleksi pada hari ke 14 dan kadar air sekum pada akhir penelitian. Penentuan kadar air feses dan sekum mengikuti prosedur analisis kadar air menurut AOAC (2005).

\section{Pemeriksaan Kadar MDA}

Pemeriksaan kadar malonaldehide (MDA) darah dilakukan dengan metode Thiobarbituric acid substances (TBARS) dilakukan di Laboratorium Gizi PAU Pangan dan Gizi UGM Yogyakarta. Pemeriksaan MDA mengikuti metode Capeyron dkk. (2002). Nilai TBARS dinyatakan dalam $\mathrm{mmol} / \mathrm{l}$. Sedangkan nilai TBARS hati dinyatakan dalam nmol MDA/g jaringan hati.

\section{Analisis Statistik}

Data yang diperoleh pada penelitian dianalisis menggunakan uji RAL Faktorial-Anova. Jika perlakuan menunjukkan pengaruh yang nyata, maka dilanjutkan dengan uji Duncan.

\section{HASIL DAN PEMBAHASAN}

\section{Kadar Air Feses Hewan Sesudah 1 Minggu Perlakuan dengan EPEC ATCC 35218}

Hasil analisis SPSS menggunakan Anova memperlihatkan bahwa ada interaksi nyata $(\mathrm{p}<0,05)$ antara perlakuan enteropathogenic E.coli atau EPEC ATCC 35218 dan pemberian yogurt dengan probiotik indigenous terhadap kadar air feses pada tikus uji. Interaksi antar perlakuan terhadap kadar air feses dapat dilihat pada Gambar 2.

Gambar 2 menunjukkan fenomena bahwa tanpa paparan enteropathogenik Escherichia coli (EPEC) ATCC 35218, probiotik Lactobaciluus plantarum Dad 13 menaikkan kadar air feses tikus coba, sedangkan dengan paparan enteropathogenik Escherichia coli (EPEC) ATCC 35218, probiotik Lactobaciluus plantarum Dad 13 menurunkan secara nyata kadar air feses tikus coba. Adanya peningkatan kadar air feses pada kelompok tikus uji tanpa paparan EPEC ATCC 35218 dimungkinkan karena pengaruh asam pada yogurt ekstrak ubi jalar ungu, namun kadar air feses kedua kelompok tikus tersebut masuk dalam kisaran normal, yaitu di bawah 60\%. Spehlman dkk. (2009) melaporkan bahwa kadar air feses normal tikus adalah di bawah $60 \%$, kejadian diare pada tikus ditandai dengan feses yang lembek dan kadar air di atas $60 \%$, sedangkan diare sangat parah pada tikus ditandai dengan feses yang cair dan kadar air di atas $80 \%$.

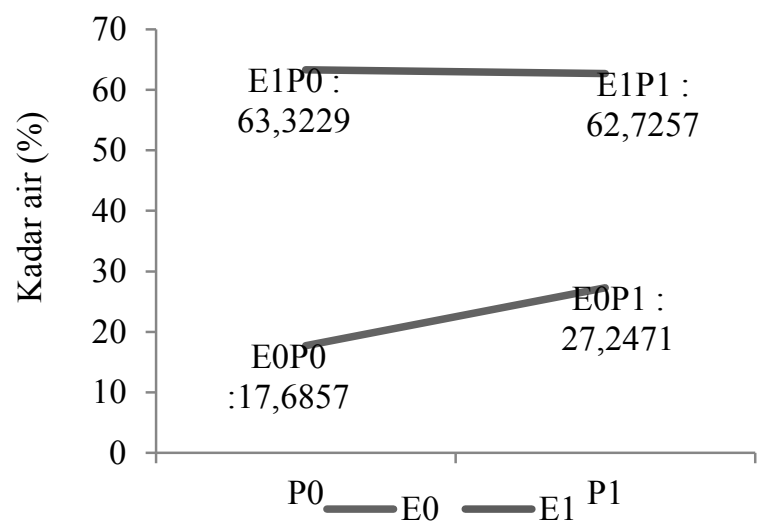

Keterangan : Eo = tanpa E.coli, E1= dengan E.coli

$\mathrm{Po}=$ tanpa probiotik, $\mathrm{P} 1=$ dengan Probiotik

Gambar 2. Pengaruh interaksi penambahan probiotik pada yogurt dan paparan enteropathogenik Escherichia coli (EPEC) ATCC 35218 pada tikus uji terhadap kadar air feses

Gambar 2 juga memperlihatkan bahwa adanya perlakuan paparan EPEC ATCC 35218 menyebabkan terjadinya peningkatan kadar air feses, baik pada kelompok tikus EIP0 maupun E1P1, dengan rata-rata kadar air diatas $60 \%$ yang menandakan kejadian diare. Kelompok tikus uji E1P1 walaupun mengalami kejadian diare, namun kadar air sedikit lebih rendah daripada kelompok tikus uji E1P0. Hal ini dimungkinkan karena adanya probiotik pada yogurt ekstrak ubi ungu mampu melakukan mekanisme perlindungan terhadap bakteri EPEC ATCC 35218. Menurut Collado dkk. (2007) mekanisme perlindungan bakteri probiotik terhadap bakteri pathogen antara lain melalui kompetisi penempelan pada sisi ikatan dan nutrient, memodulasi sistem imun dan sekresi senyawa anti mikrobia. Pada Gambar 2 terlihat bahwa selisih kadar air feses kelompok E1P1 dengan E1P0 sangat kecil, hal ini dimungkinkan karena mekanisme perlindungan probiotik yang terkandung pada yogurt ekstrak ubi jalar ungu tersebut belum maksimal bekerja dalam 1 minggu setelah perlakuan paparan EPEC ATCC 35218.

\section{Kadar Air Sekum Tikus Uji dengan Perlakuan EPEC ATCC 35218}

Sekum adalah kantong yang terletak antara usus kecil dan usus besar. Sekum pada tikus merupakan tempat berlangsungnya fermentasi zat-zat makanan oleh mikroflora usus (Liong dan Shah, 2006). Kadar air sekum merepresentasikan keberadaan dan kemampuan bakteri asam laktat probiotik L. plantarum Dad 13 melawan kejadian diare yang disebabkan oleh EPEC ATCC 35218 yang diberikan pada penelitian ini. Kadar air sekum analog dengan kadar air feses tikus coba. Spehlman dkk. (2009) melaporkan bahwa kadar air feses normal tikus adalah di bawah $60 \%$, kejadian 
diare pada tikus ditandai dengan feses yang lembek dan kadar air di atas $60 \%$, sedangkan diare sangat parah pada tikus ditandai dengan feses yang dair dan kadar air di atas $80 \%$.

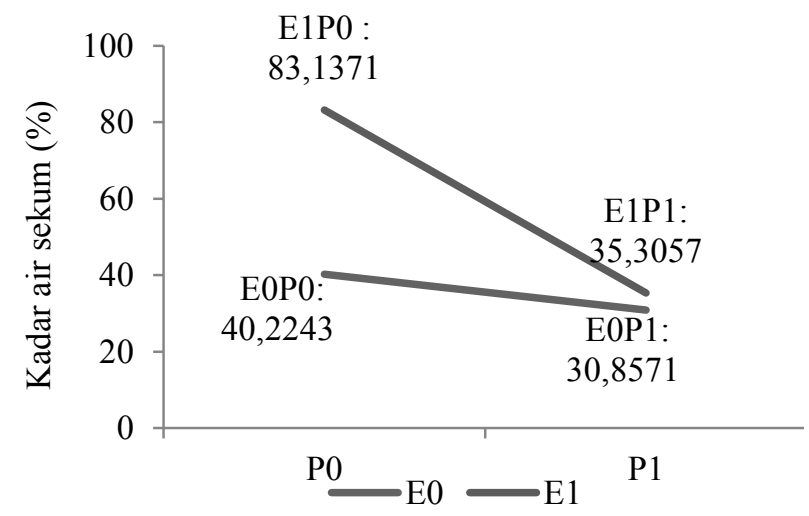

Keterangan $:$ Eo $=$ tanpa E.coli, E1= dengan E.coli

$\mathrm{Po}=$ tanpa probiotik, $\mathrm{P} 1=$ dengan Probiotik

Gambar 3. Pengaruh interaksi penambahan probiotik pada yogurt dan paparan enteropathogenik Escherichia coli (EPEC) ATCC 35218 pada tikus uji terhadap kadar air sekum

Gambar 3 menunjukkan fenomena bahwa probiotik Lactobaciluus plantarum Dad 13 mampu menurunkan secara sangat nyata $(\mathrm{p}<0,01)$ kadar air sekum tikus uji dengan maupun tanpa paparan enteropathogenik Escherichia coli (EPEC) ATCC 35218. Adanya perlakuan paparan EPEC ATCC 35218 pada kelompok tikus E1P0 dan E1P1 menyebabkan kedua kelompok tikus tersebut mengalami diare (ditandai dengan kadar air lebih dari 60\% pada kelompok tikus uji E1P0), namun kelompok tikus E1P1 mempunyai kadar air lebih rendah dari pada kelompok tikus E1P0. Hal ini menunjukkan bahwa probiotik yang terdapat pada yogurt ekstrak ubi jalar ungu yang diberikan pada kelompok tikus E1P1 sudah bekerja dan mampu menghambat populasi enteropathogenik Escherichia coli (EPEC) ATCC 35218 pada sekum tikus uji dikarenakan tidak terganggu kondisi lingkungan luar. Hasil penelitian ini hampir sama dengan penelitian yang dilakukan oleh Madelin-Pena (2009) yang menyatakan bahwa bakteri probiotik mampu menghambat kolonisasi Enterohemorhragic Escherichia coli (EHEC). Seperti diketahui jenis probiotik yang ditambahkan pada yogurt ekstrak ubi jalar ungu adalah Lacobacillus plantarum Dad 13. Menurut Reque dkk. (2000) dan Hata dkk. (2010) penghambatan terhadap E. coli oleh $L$. plantarum karena probiotik tersebut menghasilkan senyawa antimikrobia berupa asam laktat yang bersifat bakterisidal, dan bakteriosin.

\section{Kadar Malonaldehide (MDA) Darah Tikus Uji dengan Perlakuan EPEC ATCC 35218}

Malonaldehide (MDA) adalah hasil peroksidasi lipida, merupakan indikator terjadinya stress oksidatif pada jaringan dan sel (Koltas dkk., 2006). Stres oksidatif menggambarkan kondisi kerusakan oksidatif yang terjadi ketika keseimbangan antara radikal bebas dan antioksidan tidak berjalan dengan baik. Stres oksidatif dapat disebabkan antara lain karena kejadian diare yang juga mengganggu sistem imun.

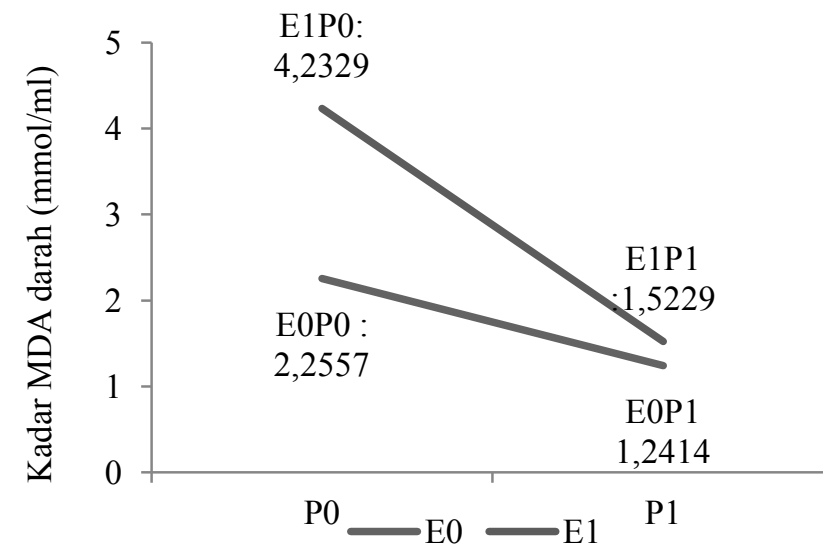

Keterangan : Eo $=$ tanpa E.coli, E1 $=$ dengan E.coli

$\mathrm{Po}=$ tanpa probiotik, $\mathrm{P} 1=$ dengan Probiotik

Gambar 4. Pengaruh interaksi penambahan probiotik pada yogurt dan paparan enteropathogenik Escherichia coli (EPEC) ATCC 35218 pada tikus uji terhadap kadar malonaldehide (MDA) darah

Gambar 4 memperlihatkan fenomena bahwa probiotik Lactobacillus plantarum Dad 13 mampu menurunkan radikal bebas yang diindikasikan dengan menurunnya kadar malonaldehide (MDA) darah, baik pada kelompok tikus yang dipapar EPEC ATCC 35218 maupun kelompok tikus tanpa dipapar EPEC ATCC 35218. Adanya perlakuan pemberian EPEC ATCC 35218 pada kelompok tikus E1P0 dan E1P1 menyebabkan kedua kelompok tikus tersebut mengalami diare yang juga menyebabkan stres. Keadaan stres inilah menyebabkan kenaikan radikal bebas dalam darah secara tidak langsung

Kelompok tikus E1P1 memperlihatkan kadar MDA lebih rendah daripada kelompok tikus E1P0. Hal ini dimungkinkan karena peran ekstrak ubi jalar ungu secara tidak langsung yang disuplementasikan pada yogurt ekstrak ubi jalar ungu. Hasil penelitian ini sejalan dengan penelitian Retnati (2009) menunjukkan bahwa proses fermentasi pada pembuatan yoghurt dengan penambahan ubi jalar ungu dapat meningkatkan aktivitas antioksidan, sehingga berpotensi mengurangi kadar lipid dalam darah. Adanya penambahan 
ekstrak ubi jalar dalam pembuatan yogurt dapat menghalangi laju perusakan sel oleh radikal bebas. Selain itu dengan adanya penambahan ekstrak ubi jalar ungu sebagai prebiotik meningkatkan jumlah probiotik. Menurut Collado dkk. (2007) probiotik memberikan mekanisme perlindungan terhadap bakteri pathogen antara lain melalui kompetisi penempelan pada sisi ikatan dan nutrient, memodulasi sistem imun dan sekresi senyawa anti mikrobia.

\section{Kadar Malonaldehide (MDA) Hati Tikus Uji dengan Perlakuan EPEC ATCC 35218}

Tikus yang dipapar oleh EPEC akan mengalami stres. Keadaan stress ini memungkinkan meningkatkan radikal bebas dalam tubuh secara tidak langsung. Jumlah radikal bebas ditunjukkan dengan meningkatnya kadar MDA (malonaldehide), dan kedua hal tesebut berjalan beriringan (Astuti dkk., 2009).

Gambar 5 memperlihatkan fenomena bahwa probiotik Lactobacillus plantarum Dad 13 mampu menurunkan sangat nyata $(\mathrm{p}<0,01)$ radikal bebas yang diindikasikan dengan menurunnya kadar malonaldehide (MDA) hati baik pada kelompok tikus E0P1 maupun E1P1. Hal ini dimungkinkan karena peran ekstrak ubi jalar ungu secara tidak langsung yang disuplementasikan pada yogurt ekstrak ubi jalar ungu. Ubi jalar ungu selain berfungsi sebagai prebiotik dengan jalan memberikan efek kesehatan bagi tubuh inangnya dengan cara memacu pertumbuhan probiotik (bakteri menguntungkan) dalam usus besar (Gibson dan Fuller, 1998), juga mengandung anthocyanin yang merupakan zat anti oksidan yang mampu mengurangi terjadinya radikal bebas yang diindikasikan dengan keberadaan MDA (malonaldehide).

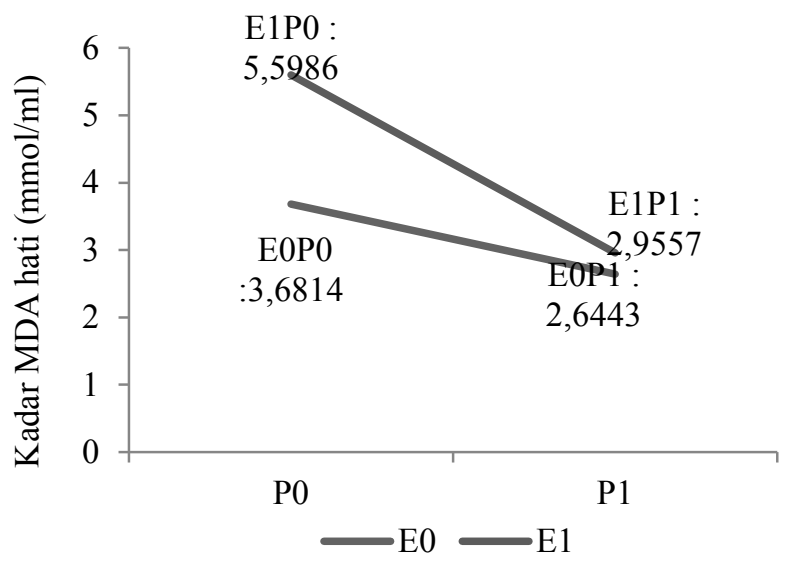

Keterangan : Eo= tanpa E.coli, E1= dengan E.coli

$\mathrm{Po}=$ tanpa probiotik, $\mathrm{P} 1=$ dengan Probiotik

Gambar 5. Pengaruh interaksi penambahan probiotik pada yogurt dan paparan enteropathogenik Escherichia coli (EPEC) ATCC 35218 pada tikus uji terhadap kadar malonaldehide (MDA) hati
Gambar 5 juga memperlihatkan bahwa adanya perlakuan paparan EPEC ATCC 35218 pada kelompok tikus E1P0 dan E1P1 menyebabkan kedua kelompok tikus tersebut mengalami diare yang juga mengganggu sistem imun tikus dan akhirnya menyebabkan stres. Keadaan stress ini menyebabkan kenaikan radikal bebas dalam tubuh secara tidak langsung, yang kemudian mengendap dalam hati. Kelompok tikus E1P1 memperlihatkan jumlah MDA lebih rendah daripada kelompok tikus E1P0 hal ini karena adanya mekanisme perlindungan dari bakteri probiotik terhadap bakteri pathogen antara lain melalui: (1) penghambatan pathogen melalui kompetisi nutrisi, penurunan $\mathrm{pH}$ dan poduksi bakteriosin, (2) penghambatan produksi dan penerimaan toksin, (3) penghilangan sifat virulensi, (4) peningkatan sistem imunitas (Fooks dkk., 1999) dan kemampuan adhesi (penempelan) probiotik pada mukosa usus (Ouwehand dkk., 1999). Menurut Preidis dan Versalovic (2009), beberapa probiotik mampu memodulasi sistem imun dalam saluran pencernaan melalui produksi faktor sekreta dan metabolit yang mempengaruhi pertumbuhan dan fungsi epitel usus serta sel imun.

\section{KESIMPULAN}

Terdapat interaksi antara pemberian Enteropathogenic Escherichia coli (EPEC) ATCC 35218 dan probiotik indigenous (Lactobacillus plantarum Dad 13) pada yogurt ekstrak ubi jalar ungu terhadap kadar air feses, kadar air sekum, kadar MDA darah dan kadar MDA hati tikus uji. Kultur Lactobacillus plantarum Dad 13 yang ditambahkan pada yogurt ekstrak ubi jalar ungu mampu memberi efek kesehatan, karena mempunyai potensi penurun diare dan radikal bebas.

Penelitian lanjutan dengan perlakuan pemberian probiotik indigenus (Lactobacillus plantaraum Dad 13) pada yogurt dengan suplementasi ekstrak ubi jalar ungu dan perlakuan EPEC ATCC 35218 secara in vivo perlu dilakukan dengan pengujian menggunakan kontrol negatif untuk mengetahui gambaran hematologi dan mikrobiologis saluran pencernaan tikus serta efek nyata dari ubi jalar ungu sebagai prebiotik.

\section{UCAPAN TERIMA KASIH}

Peneliti mengucapkan terima kasih kepada Dirjen Dikti yang telah membiayai penelitian ini melalui dana penelitian Desentralisasi Hibah Bersaing tahun anggaran 2014. 


\section{DAFTAR PUSTAKA}

AOAC. (2005). Official Methods of Analysis.Washington, DC.

Astuti S., Muchtadi, D., Astawan, M., Purwantara, B. dan Wresdiyati, T. (2009). Pengaruh pemberian tepung kedelai kaya isoflavon terhadap kadar malonaldehide (MDA), aktivitas supeoksida dismutase (SOD) testis dan profill $\mathrm{Cu}, \mathrm{Zn}$-SOD tubuli seminferi testis tikus jantan. Jurnal Teknologi dan Industri Pangan 20(2): 129-134.

Bourlioux, P., Koletzko, B., Guarner, F. dan Braesco, V. (2003). The intestinal and its microflora are partners for protection of host: report on the Danone Symposium 'The Intelligent Intestine' held in Paris, June 14, 2002. The American Journal of Clinical Nutrition 78: 675683.

Codex standard 243, 2003. http://www.codexalimentarius. com/codex stan 243-2003. [7 Agustus 2013].

Collado, M.C., Surono L.S., Meruluoto J. dan Salminen (2007). Potential probiotic characteristics of Lactobacillus and Enterococcus strains isolated from traditional dadih fermented milk against pathogen intestinal colonization. Journal of Food Protection 70: 700-705.

Capeyron, Julie C., Eric B, Jean P., Piere, M.R., Claude, L.L. dan Benard D. (2002) A diet cholesterol and deflcient in vite incudes lipid peroxidation but does not enhace antioxidant enzyme expression in rat liver. Jurnal Biochemistry 13: 296-301.

FAO (2002). Guidelines for the Evaluation of Probiotics in Food. Report of Joint FAO/WHO Working Group on drafting Guidelines for the evaluation of probiotics in food. London Ontario, Canada.

Fooks, L.J., Fuller, R. dan Gibson, G.R. (1999). Prebiotics, probiotics and human gut microbiology. Probiotica 9 : 2-7.

Gackowska, L., Michalkiewics, J., Krotkiewski, M., Helmin, B.A, Kubiszewska, I. dan Dzierzanowska, D. (2006). Combiner effect of different lactic acid bacteria strain on the mode of cytokines pattern expression in human periperal blood monoclearcells. Journal of Physiology and Pharmacolology 57(9): 13-21.

Gibson, G.R. dan Fuller, F. (1998). The role of probiotics and prebiotics in the fuctional food concept. Dalam: Sadler, M.J. dan Saltmash, M. Functional Foods the Consumers, the Products and the Evidence, hal 3-13. British Nutrition Foundation.
Hata, T., Tanaka, R. dan Ohmomo, S. (2010). Isolation and characterization of plantaricin ASM 1: a new bacteriocin produced by Lactobacillus plantarum A-1. International Journal of Food Microbioogy 137: 94-99.

Koltas, I.S., Yucebilgic, G., Bilgin, R., Parsak, C.K. dan Sakman, G. (2006). Serum malonaldehide level in patien with cystic achinococcocis. Journal of Saudi Medicine 27: 1703-1705.

Liong, M.T. dan Shah, N.P. (2006). Effec of Lactobacillus casei symbiotic on serum lipoprotein, intestinal microflora and organic acids in rats. Journal of Dairy Science. 89: 1390-1399.

Madellin-Pena, M.J. dan Griffith, M.W. (2009). Effect of molecules secreted by Lactobacillus acidophilus strainLa-5 on Escherichia coli O157:H7 colonization. Applied Environmental Microbiology 75: 1165-1172.

Muchtadi, D. (1993). Teknik Evaluasi Nilai Gizi Protein. Program Pasca Sarjana. Institut Pertanian Bogor, Bogor.

Ngatirah, Harmayani, E., Rahayu, E.S. dan Utami, T. (2000). Seleksi bakteri asam laktat sebagai agensia probiotik yang berpotensi menurunkan kolesterol. Paper dalam Prosiding Seminar Nasional Industri Pangan. Surabaya 10-11 Oktober 2000.

Oeytayo, V.O. (2004). Performance of rats orograstically dosed with faecal strain of Lactobacillus acidophilus and chalenged with Escherichia coli. African. Journal of Biotecnology 3: 409-411.

Ouwehand, A.C., Kirjavainen, P.V., Shot, C. dan Salminen, S. (1999). Probiotics: mecanism and established effect. International Dairy Journal 9: 43-52.

Parvez, S., Malik, K.A., Ah Kang, S. dan Kim, H.Y. (2006). Probiotics and their fermented food products are beneficial for health. Review article. Journal of Applied Microbiobology 100: 1171-1185.

Preidis, G. dan Versalovic, J. (2009). Targeting the human microbiome with antibiotics, probiotics, and prebiotics: gastroenterology enters the metagenomics era. Gastroenterology 136: 2015-2031.

Purwandani, S.N. dan Rahayu, E.S. (2003). Isolasi dan seleksi Lactobacillus yang berpotensi sebagai agensia probiotik. Agritech 23: 67-74.

Rahayu, E.S., Djafar, T.F., Wibowo, D. dan Sudarmadji, S. (1996). Lactic acid bacteria from indigenous fermented food and their antimicrobial activity. Indonesian Food and Nutrition Progress 3: 21-28.

Rastall, R.A. dan Gibson, G.R. (2004). Functional food. Bioscience Explained 2: 1-7. 
Reque, E.F., Pandey, A., Franco, S.G. dan Soccol, R. (2000). Isolation, identification and physiological study of Lactobacillus acidophilus LPB for use as probiotic in chickens. Brazilian Journal of Microbioogy 31: 303-307.

Retnati (2009). Pengaruh Penambahan Ekstrak Berbagai Jenis Ubi Jalar (Ipomoea batatas L) terhadap Jumlah Sel dan Aktivitas Antioksidan Yoghurt. Skripsi. Fakultas Pertanian Universitas Sebelas Maret, Surakarta.

Nagendra, S.P. (2000). Probiotic bacteria: selective enumeration and survival in dairy food. Jurnal of Dairy Science 83: 894-907.

Spehlman, M.E., Dann S.M., Hrus, P., Hanaon, E., Mc.Cole, D.F. dan Eckmann (2009). CXCR2-dependent mucosal neutrophil influx protects against colitis-associated diarrhea caused by an attaching/efficacing lesionforming bacterial pathogen. The Journal of Immunology 183: 3333-3343.
Tari, A.I.N. (2011). Ipoviola (ubi jalar ungu) sebagai susu prebiotik: Kajian penambahan jenis susu terhadap sifat kimia-organoleptiknya. Prosiding Seminar Hasil Penelitian dan Pengabdian Kepada Masyarakat, ISBN: 978-602-99172-5-3, Lembaga Penelitian dan Pengabdian kepada Masyarakat Universitas Veteran Bangun Nusantara Sukoharjo. Hal.:13-22.

Tari, A.I.N., Handayani, C.B. dan Mursyid, A.W.M. (2013). Bakteri probiotik terhadap mutu yogurt ekstrak ubi jalar ungu dan pemanfaatannya sebagai pencegah diare dan imunomodulator. Laporan Penelitian Hibah Bersaing. Universitas Veteran Bangun Nusantara. Sukoharjo.

Woolfe, J. (1993) Sweet Potato: An Untapped Food Resource. Cambridge University Press, Cambridge. 